403 MORITZ SCHRAMM

Lektor ved Institut for Kulturvidenskaber, Syddansk Universitet

\title{
KRITIKKENS FORSKELLIGE FUNDAMENTER
}

Axel Honneth \& Jacques Rancière

RECOGNITION OR

DISAGREEMENT

A Critical Encounter on the Politics

of Freedom, Equality and Identity

Columbia University Press, New York, 2016

Man kan være positiv eller kritisk overfor Axel Honneths anerkendelsesteori, der har fyldt en del i de seneste års filosofiske debatter. En ting, man imidlertid ikke kan bebrejde den tyske filosof, der til daglig er leder af det berømte Institut für Sozialforschung i Frankfurt, er manglende vilje til at engagere sig i kritiske dialoger med andre teoretikere. Hans udvekslinger og dialoger med eksempelvis Joel Whitebook, Luc Boltanski,
Nancy Fraser og Judith Butler har affødt fælles bøger, kritiske læsninger eller særnumre i videnskabelige tidsskrifter og er ofte blevet set som højdepunkter i de respektive teoriers videre udvikling. ${ }^{1}$ Samtidig skriver

1 Se f.eks.: Nancy Fraser og Axel Honneth: Redistribution or Recognition? A Political-Philosophical Exchange. London: Verso, 2003; se med hensyn til diskussionen med Whitebook o.a. "Mutual Recognition and the Work of the Negative" i W. Rehg (red.): Pluralism and the pragmatic turn. Cambridge/Mass: MIT Press, 2001: 257-291; Axel Honneth: "Facets of the Prosocial Self: A rejoinder to Joel Whitebook" i The I and the We: Studies in the Theory of Recognition. Cambridge: Polity, 2012; Joel Whitebook: “Die Gren- 
404 KULTUR \& KLASSE * $122 * 2016$ ANMELDELSER

den slags teoretiske udvekslinger sig ind i den lange tradition af filosofiske dialoger, som ikke mindst Honneths forgænger som leder af Institut für Sozialforschung i Frankfurt, Jürgen Habermas, der blandt andet engagerede sig i forskellige udvekslinger og dialoger med Jacques Derrida, er kendt for. ${ }^{2}$

zen des intersubjektiven turns: Eine Erwiderung auf Axel Honneth" i Psyché, nr. 3, 2003; udvekslingen med Boltanski fandt sted i Frankfurt, hvor Honneth inviterede ham til at holde Adorno-forelæsningerne; 2008 (se Luc Boltanski: On Critique. A Sociology of Emancipation. Cambridge: Polity, 2011); dialogen med Butler har udfoldet sig såvel i Frankfurt, hvor hun blev inviteret til at give Adorno-forelæsningerne i 2003 (Giving an Account of Oneself. Fordham, 2005), som i Berkeley, hvor Honneth gav sine Tanner-lectures om tingsliggørelse, som Butler kommenterede efterfølgende (se Reification. A New Look to an Old Idea. OUP, 2008, inkl. Butlers kommentarer); se også Honneths diskussion af Althussers syn på anerkendelse i hans essay "Recognition as Ideology", der kan læses som en videreudvikling af dialogen med Butler (i Bert van den Brink (red.): Recognition and Power: Axel Honneth and the Tradition of Critical Theory. Cambridge University Press, 2010: 323-348).

2 Se f.eks.: Giovanna Borradori (red.): Philosophy in a Time of Ter-
Axel Honneth og Jacques Rancières fælles bog Recognition or Disagreement. A Critical Encounter on the Politics of Freedom, Equality and Identity kan læses som det nyeste skud på stammen. ${ }^{3}$ Den bygger på et møde mellem Honneth og Rancière, der fandt sted på Frankfurter Institut für Sozialforschung i 2009. Mødet tog afsæt i de to filosoffers kritiske læsninger af den andens teori, før de engagerede sig på scenen i en dialog, der er transskriberet og offentliggjort i bogen. Den tyske filosof Christoph Menke er ordstyrer på diskussionen.

Bogen er imidlertid ikke begrænset til de to filosoffers diskussion og de tekster, i hvilke de kritisk forholder sig til hinandens teori. Den falder snarere i tre dele, hvoraf den første "Setting the Stage" - består af tekster af hhv. Katia Genel og Jean-Philippe Deranty, der introducerer baggrunden for mødet og kommer bag om de to filosoffers positioner, som de sam-

ror: Dialogues with Jürgen Habermas and Jacques Derrida. Chicago: Chicago University Press, 2003.

3 Axel Honneth og Jaques Rancière: Recognition or Disagreement. A Critical Encounter on the Politics of Freedom, Equality and Identity. New York: Columbia University Press, 2016. Sidetal i teksten henviser til denne udgave. 
menligner og sætter i deres respektive traditioners kontekst. Anden del, "Critical Encounter", indeholder Honneth og Rancières læsninger af hinandens teorier og nævnte transskription af diskussionen i Frankfurt. Bogen afsluttes med en tredje del, "The Method of Critical Theory: Propositions", der indeholder et essays af hhv. Honneth og Rancière, i hvilke de uddyber deres positioner og giver et indblik i fundamentet for deres kritiske teorier.

\section{OVERENSSTEMMELSER OG FORSKELLE}

Bogens omdrejningspunkt er i bund og grund nutidens mulighed for en kritisk socialfilosofi. Og den vinder styrke ikke mindst i kraft af de fine introduktioner, som hhv. Genel og Deranty i første del står for. Her gives ikke blot en introduktion til selve mødet og til de forskellige positioner, som hhv. Honneth og Rancière fremlægger i anden del; de to formår desuden at komme bagom de udvekslede argumenter ved at placere dem i deres respektive traditioner og dermed give læseren nyttige baggrundsinformationer om de to filosoffers ståsted og de uoverensstemmelser, der bliver synlige senere i bogen. Genel og Deranty præsterer på få sider at tilbyde en dybdegå- ende, kritisk og samtidig empatisk forståelse for de to filosoffers positioner, den indre udvikling i deres forfatterskaber og den filosofiske linje, de hver især kommer fra og skriver sig ind i.

Imponerende er ikke mindst, hvordan begge i deres indledende tekster peger på såvel overensstemmelser som forskelle mellem de to teoretikere. Overensstemmelserne består ikke kun i, at de begge er optaget af spørgsmål om anerkendelse i deres teorier - noget, der især er interessant med henblik på Rancière, som man typisk ikke læser som anerkendelsesteoretiker - men også i det grundlæggende projekt, de hver især er engageret i. Begge følger nemlig langt hen ad vejen den samme grundlæggende dagsorden. For begge gælder det for det første, at de anser kritik som en "diagnosis of the present and as an engaged praxis" i stedet for at se det som udelukkende teoretisk model (8). For det andet bruger de det historiske materiale som kilde til en kritisk undersøgelse af samfundet; i modsætning til "purely conceptual approaches" i kritisk teori, står de begge to for en traditionslinje, der er præget af "thinkers working mainly with references in European philosophy who conduct their work on social and 
political issues in direct connection with real existing social and historical phenomena" (35). Begge bruger med andre ord historiske kilder og materialer og udvikler deres teorier i direkte udveksling med den historiske fakticitet, de er omgivet af. For det tredje er de begge optaget af den samme grundlæggende bevægelse, der, med Derantys ord, består i at "fulfil a universalistic commitment to 'emancipation'" (36). Begge tager afsæt i en forestilling om en eksisterende form for "social domination", som skal overvindes; de sigter begge efter at kortlægge "the attempt by a group or a class to 'emancipate themselves' from particular oppressive social conditions" (36). Og siden de begge tager afsæt i historiske materialer, giver de begge i deres teorier plads til "the actual demands of individuals and groups without distorting, suspecting, or rejecting them" (48). De tager dem snarere "as epistemic and practical guidelines" (48). Genel skriver på tilsvarende vis i sin tekst: "Both philosophers endeavored to explain a specific phenomenon: not submission to the existing order, but the overthrow or the subversion of this order" (25).

Det afgørende er selvfølgelig, at begge arbejder med vidt forskellige opfattelser af "emancipation" og de historiske processer bag. Hvor Rancière arbejder med en idé om lighed, der skal udfordre politi-ordenen og det berømte partage du sensible, tager Honneth afsæt i forskellige former for individuel frihed, der danner det normative grundlag for en kritisk analyse af nutiden og historien. Med Derantys ord: Grundlaget er "individual freedom for Honneth, equality for Rancière; normative reconstruction versus equality of intelligence" (48). ${ }^{4}$

De to filosoffers gensidige læsninger og deres indbyrdes diskussion, som anden del af bogen består af, udfolder disse forskellige

4 Honneths koncept om "normativ rekonstruktion", som han især fremlægger i hovedværket for den sene fase i forfatterskabet, Das Recht der Freiheit (Frankfurt am Main: Suhrkamp, 2011), bygger på forestillingen om at de kritiske normer kan udledes - rekonstrueres - ud fra historiens egne kilder. Der er altså tale om en immanent kritik. Metoden er på det seneste blevet kritiseret fra forskellige sider, se blandt andet: Jörg Schaub: "Misdevelopments, Pathologies, and Normative Revolutions: Normative Reconstruction as Method of Critical Theory" i Critical Horizons, vol. 16, nr. 2, 2015: 107-130. Se også Honneths respons på kritikken i samme nummer af tidsskriftet, side 204-226. 
positioner. Ikke helt overraskende fokuserer Rancière i sin læsning af Honneths anerkendelsesteori især på subjekt-begrebet og på Honneths forestilling om personlig integritet som et positivt ideal. I modsætning til Honneth, der i bund og grund arbejder ud fra en idé om et vellykket selvforhold, insisterer Rancière på "that the demand not to be assigned to an identity must be heard" (25). Godt nok medgiver Rancière, at Honneth arbejder med et dynamisk identitetsbegreb; bag hans forestilling om en løbende "enrichment of enlargement of identity" finder han imidlertid en "process of progressive integration", der grundlæggende er bygget omkring en "telos of integrity" (92). Imod det stiller Rancière sin kendte forestilling om "subjectivization", der indeholder en proces af "dis-identification" (92). Kritikken mod Honneth er med andre ord rettet mod hans subjekt-begreb og hans - ifølge Rancière - alt for simple og endimensionale forestilling om frihed og emancipation.

Honneth retter for sit vedkommende især sin kritik mod Rancières forestilling om lighed, som han læser som et udefra kommende koncept, som ikke er udviklet med afsæt i empiriske analyser. Det er derfor, ifølge Honneths argument, svært at se, hvordan et begreb om lighed kan tjene som udgangspunkt for historiske processer. Desuden retter han en stærk kritik mod Rancières - ifølge Honneth - alt for endimensionale koncept af politi-ordenen, "police order" (103). Mens Honneth er enig i en del af Rancières konkrete beskrivelser - deriblandt i hans argument om en fordeling af det sanselige - mistænker han, at Rancières "description of such a political-social order is too rigid or too overregulated" (103f.). Bag denne kritik ligger den klassiske pointe, som vi har set udfoldet mange gange i teoretiske udvekslinger mellem franske og tyske varianter af den kritiske teori: at en alt for generaliserende beskrivelse af det bestående umuliggør en intern politisk forandring af den bestående orden. Den eneste udvej består, når man først har defineret den sociale orden som undertrykkende i sig selv, i en tilbagetrækning til det æstetiske (som bl.a. Adorno blev kritiseret for), eller en revolutionær "interruption" af det bestående (i Rancières tilfælde, 105). Imod en sådan endimensional forståelse af den politiske orden sætter Honneth i sin tekst to forskellige former for politiske interventioner, der skal forandre den eksisterende sociale orden, som han konsekvent omtaler som "recognitional order" 
- altså som den normative horisont, der bestemmer, hvem der bliver anerkendt og for hvad. Den første form for politisk intervention, som han betegner som "internal struggle for recognition", retter sig kritisk mod den til en given tid herskende sociale orden, dog uden at selve det normative grundlag for den sociale orden udfordres. Denne form for anerkendelseskamp foregår internt $i$ en social orden, den "does not call into question the existing principles of recognition or the existing principles normative legitimation, but calls into question the existing modes of their interpretation" (105). I denne anerkendelseskamp bevares altså den grundlæggende normative idé bag en social orden, mens dens tolkning udvides eller kritiseres. Det handler, ifølge Honneth, om "to reidentify your own community with reference to a new interpretation of the already accepted normative principles" (105). Over for en sådan kritisk intervention stiller Honneth det mere radikale opgør med den eksisterende normative orden. Den anden form for politisk intervention, som Honneth kalder "external struggle for recognition", sigter ikke efter "an improvement of the application of one principle, but at an overcoming of the authority of the order as such" (105). Over for en politisk reformproces, som Honneth tydeligvis mest abonnerer på, står så den sjældne revolutionære omvæltning af det bestående. Og problemet med Rancières koncept af det politiske er, ifølge Honneth, at det udelukkende sigter efter den anden dimension og dermed udelukker enhver form for demokratisk reformproces. Honneth skriver:

I don't want to deny the possibility of revolution, but I think that the disadvantage of reserving the notion of the political only for those kinds of total interruption is that we are forced to ignore the daily experiences of revolt and political subversion, which does not aim at, and are not necessary for, overcoming the political order as such, but which have a more (we would say traditionally) 'reformist' ambition, that is, the ambition to simply reinterpret the existing normative principles (106).

\section{INDSIGTER OG \\ PERSPEKTIVER}

Bag de gensidige kritikpunkter viser sig således to forskellige tilgange til kritisk praksis. Især hvad Honneths position angår er det tydeligt, at den ligger i forlængelse af det interne opgør i Frankfurterskolen, som vi så i 1980'erne, hvor først Habermas og senere Honneth afviste Theodor W. 
Adornos alt for endimensionelle fornuftbegreb og forsøgte at reetablere en kritisk samfundsteori, der ikke nødvendigvis ender i negativ dialektik, men derimod kan åbne sig for de politiske processer, som de vesteuropæiske demokratier muliggjorde. Honneths kritik mod Rancière bygger på tilsvarende vis på en teoretisk tilgang, der sigter efter at reaktualisere oplysningsprojektet: den individuelle frihed, den personlige integritet og deltagelsen i den politiske offentlighed er omdrejningspunkter i Honneths anerkendelsesteori, der adskiller ham fra Rancières identitetskritiske og dermed langt mere radikale opgør med oplysningsværdierne. Og ulempen for Honneth er også, som det de seneste år flere gange er blevet påpeget, at han med sin metode om en "normativ rekonstruktion" nærmest nødvendigvis abonnerer på en reformdagsorden, der ikke giver meget plads for en "radical critique" af det bestående, som nogle kritikere har bemærket. ${ }^{5}$

5 Schaub op.cit., side 107. Se også: Fabian Freyenhagen: "Honneth on Social Pathologies: A Critique" i Critical Horizons, vol. 16, nr. 2, 2015 , side 131-152, der på tilsvarende vis antager, at Honneth af strukturelle grunde ender i en "reformist project", der er blind for de mere radikale kritikformer (142). I sit svar
Den grundlæggende forskel mellem Honneth og Rancière bygger derfor på forskellige syn på fundamentet for den kritiske proces. Dialogen mellem de to filosoffer, som er optrykt efter deres respektive læsninger i anden del af bogen, handler følgelig også mest om konsekvenserne af de forskellige tilgange: Hvordan er de historiske processer motiveret, hvis ikke man tager afsæt i enten et universelt frihedsbegreb eller en antropologisk forestilling om lighed, som Rancière dog voldsomt afviser? Hvad er de historiske aktørers motivation for at kritisere den eksisterende sociale orden og måden at se verden på, hvis ikke de har en individuel følelse af ubehag eller lidelse i det bestående ("suffering")? Og hvordan kan vi konceptualisere de historiske forandringer uden at

på kritikken indrømmer Honneth muligheden for en "institutional revolution" - dvs. for en grundlæggende genfortolkning af de eksisterende anerkendelsesinstitutioner - men viser sig skeptisk overfor muligheden for en "normativ revolution", der ikke bygger på frihedsidealerne (se Axel Honneth: "Rejoinder", op.cit., især side 205-217; se også Honneths videreudvikling af disse tanker i hans genlæsning af Marx i Die Idee des Sozialismus. Versuch einer Aktualisierung. Berlin: Suhrkamp, 2015). 
falde tilbage til en voldsom psykologisering, som Rancière anklager Honneth for?

Dialogen er ikke nødvendigvis præget af en tilnærmelse mellem de to filosoffer. Især Rancière viser ingen tegn på imødekommenhed overfor Honneths teoretiske afsæt, mens Honneth dog i det mindste giver udtryk for at ville vise sig åben for bestemte elementer af den andens teori, eksempelvis Rancières partage du sensible. Og de to afsluttende essays, som tredje del af bogen består af, bekræfter på tilsvarende vis de forskellige tilgange til den kritiske teori: i "The Method of Equality" giver Rancière et interessant og velfungerende indblik i sin kritiske tilgang, ikke mindst med blik på de æstetiske dimensioner i det, og i "Of the Poverty of Our Liberty" fremlægger Honneth nogle af de samme pointer, som han også har udfoldet i Das Recht der Freiheit fra 2011: Han stiller den negative frihed over for den refleksive og den sociale frihed og udarbejder en tese om de sociale institutioners rolle i muliggørelsen af den individuelle frihed.

Sammenlagt består bogens styrke altså ikke i en tilnærmelse mellem de to filosoffers positioner. Som læsning er deres fælles "encounter" alligevel dybt inspirerende: I mødet mellem de to teoretikere bliver ikke kun det fælles omdrejningspunkt for en nutidig kritisk teori synligt, men især også vanskelighederne, som de forskellige koncepter har indbygget i deres teorier: vanskeligheden ved at finde frem til kilden for historiske forandringer, muligheden for at finde det teoretiske fundament for enhver forandring og spørgsmålet om rækkeviden af en kritisk praksis mellem radikal genåbning af det politiske på den ene side og en kritisk reformproces på den anden. Og selv om jeg selv utvivlsomt hører til dem, der bakker op omkring Honneths forsøg på en reaktualisering af de historiske frihedsidealer, er åbningen til Rancière og hans mere radikale kritik givende og inspirerende-ikke mindst for de æstetiske studier, som man også kan se i de mange specialer og studenteropgaver, der i disse år anvender hans teorier. Om de politiske emancipationsprocesser, som både Rancière og Honneth gerne vil fremme, for alvor styrkes af denne radikale genåbning, eller om denne ikke snarere tager fokus væk fra de "small projects of redefintion or of appropriation of the existing modes of political legitimation" (105), som egentligt befordrer en kritisk videreudvikling af det bestående, må stå på et andet stykke papir. Honneth 


\section{MORITZ SCHRAMM}

KRITIKKENS FORSKELLIGE FUNDAMENTER

og Rancières kritiske dialog er dog givende uanset ens personlige ståsted: Den giver et imponerende og vigtigt indblik i teoriernes inderste maskinrum, befordrer den interne debat om en fremtidig kritisk praksis og muliggør desuden et interessant indblik i de fælles dagsordener bag om alle forskelle. Et stærkt og imponerende værk. • 
412 KULTUR \& KLASSE * $122 * 2016$ ANMELDELSER 